\title{
Job market for graduating urologists
}

\author{
Omar Nazif, MD, PEng, FRCSC \\ Department of Urologic Sciences, University of British Columbia, Vancouver, BC; Chair, CUA Health Policy Committee
}

Cite as: Can Urol Assoc J 2018;12(4):110-1. hitp://dx.doi.org/10.5489/cuai.5271

See related article on page 104

I n Canada, there has been a perception that urology graduates are challenged finding employment, but little has been published. The timely work by Hosier et al opens a window into the views of Canadian PGY-5 urology residents in the later stages of training. ${ }^{1}$ This important work is validated by an accepted abstract to the Canadian Urology Association (CUA) 2018 annual meeting, "2016 Canadian urology workforce study — the graduating cohort of 2014-16," submitted by the CUA Health Policy Committee (HPC). ${ }^{2}$ The work suggests there may be a looming urology workforce crisis in Canada precipitated, in part, by overtraining residents and a shortage of economic resources to hire new urologists.

It is well-known and publicized that there has been overtraining of surgical residents in several programs, including orthopedic surgery, ENT, general surgery, and neurosurgery. There are over 100 unemployed Canadian-trained orthopedic surgeons and more graduate each year. ${ }^{1}$ Graduating surgical residents are doing more fellowships because jobs are unavailable. There is concern that urology is heading down the same road following the expansion of Canadian urology residency positions in the 2000s. In the 1990s, urology residency positions were constant at around $15 .{ }^{1}$ The number ballooned and has stayed at 33 since the 2000s; this is mostly through the expansion of Ontario programs, notwithstanding the addition of a new training program. ${ }^{3}$

There are several reasons to expect a need for more urologists in the workforce. The demographics of an aging population in Canada translates to more urological disease, a need for more care, and longer wait times without an increased workforce. ${ }^{4}$ Some suggest, perhaps privately, that new graduates value lifestyle over work and may not wish to work as hard as previous generations. Conceivably, this could lead to job-sharing, more part-time physicians, and shared resources. Others have suggested that jobs are available, but new graduates are reluctant to relocate for personal reasons.

The results of Hosier et al show that more urology residents are going on to fellowship training because they are having increasing difficulty finding a job. Only $12 \%$ of senior urology residents had secured a permanent staff position in
Canada. ${ }^{1}$ Sixty-five percent of those surveyed in 2010 and 58\% of graduates in 2016/17 rated the job market as poor or very poor. ${ }^{1}$ Urology is a resource-intensive specialty and respondents cite the lack of hospital resources as a barrier to employment. ${ }^{1}$ Despite more than doubling the number of trainees per year, there doesn't appear to be more jobs. ${ }^{1}$ The Canadian Medical Association (CMA) profile on urology shows there were 37 urologists who gave up their license from 2013-15. ${ }^{1}$ In the same time frame, there were 93 new graduates, but the number of Canadian practicing urologists remained stable at $680-690 . .^{1,5}$ Canada has an aging population that will require increased urological care, but with the Canadian Institute of Health Information $(\mathrm{CIHI})$ showing a decline $-0.1 \%$ in healthcare spending per year, there appears to be little money for resource-intensive specialties. ${ }^{6}$ Although rudimentary, this may help to understand why new graduates can't find jobs.

With a paucity of urology jobs, how are organizations like the CUA going to help? The American Urological Association

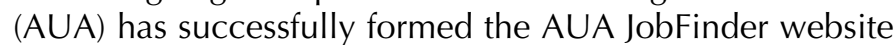
for posting new jobs. CUA HPC asked the graduates of 2014-16 how the CUA could help in their job search. The graduates asked CUA for the following: 1) create a CUA jobfinding website; 2 ) encourage programs to create five-year plans with potential local job openings; 3 ) act as a neutral party to make recommendations to residency programs on resident intake and workforce; 4) lead by encouraging job hiring transparency; 5) create mentorship program where a new graduate can work alongside a nearly retired urologist; and 6) create an environment where community urologists are celebrated, showing a rewarding lifestyle with opportunities in leadership, research, and CUA involvement. ${ }^{1}$ The CUA is actively looking into how it can better serve its members in this capacity.

More research is needed to understand what factors influence urologists to retire and to determine where new jobs are opening. These data are difficult to acquire because often job openings are unplanned with short notice, i.e., a urologist retires suddenly because of illness. Later this year, CUA HPC plans to study members of CUA over age 50 to determine their retirement plans. This will be an anonymous, self-reporting, multifaceted survey looking at what factors lead urologists to retirement.

CUA HPC asked the graduating cohort of 2014-16 about their satisfaction in the profession. Despite the difficulties 
in finding work, $56 \%$ agreed or strongly agreed they would still train to be a urologist. ${ }^{2}$ Conversely, only $40 \%$ would encourage a medical student to apply to urology. ${ }^{1}$ Most $(86 \%)$ new graduates support a contraction of residency positions across Canada. ${ }^{2}$

Most also agree that it is nonsensical to train an undifferentiated resident to be a urologist if there is no job upon graduation. It follows that wasted training is a poor use of resources and does a disservice to the taxpayer, resident, and patient. Unemployed graduates argue that residency programs are incentivized to train more residents, as they provide a well-trained labour pool to the benefit of the preceptors. ${ }^{2}$ Training programs may counter that a urology residency position doesn't come with a job guarantee. With the current shortage of family physicians, an unemployed urology graduate may have been better served by pursuing family medicine where jobs are plentiful and without geographic restriction. With that in mind, I leave you with two questions to ponder: Given the employment challenges new graduates are facing today, should Canadian urology residency programs contract the number of residency positions? Or should governments recognize that an aging population requires more urological care and allocate additional economic resources accordingly, and in so doing, create new positions for graduates?
Competing interests: Dr. Nazif has received a speaker honorarium from Janssen.

\section{References}

1. Hosier T, Touma N. Attitudes of graduating Canadian urology residents on the job market: Is it getting better or are we just spinning our wheels? Can Urol Assoc J 2017 Dec 22. Epub ahead pf print. http://dx.doi.org/10.5489/cuaj.4765

2. Nazif O, Razvi H, Nickel C, et al. Canadian urology workforce study - the graduating cohort of 2014-16. Accepted for Podium Session 3 at: $73^{\text {rd }}$ Annual Meeting of the Canadian Urological Association; June 23-26, 2018; Halifax, NS.

3. Sullivan, Patrick. Spectre of unemployment dogging new orthopedic surgeons, COA says. Canadian Medical Association; 2013. Available at https://www.cma.ca/En/Pages/Spectre-unemployment-dogging-neworthopedic-surgeons.aspx. Accessed Feb. 23, 2018.

4. Estimates of population, by age group and sex for July 1, Canada, provinces and territories. Statistics Canada Table 051-0001. Available at http://www5.statcan.gc.ca/cansim/a26?lang=eng\&rettlang $=$ eng\&id=0510001\&\&pattern=\&stByVal=1\&pl=1\&p2=50\&tabMode=dataTable\&csid $=$. Accessed Feb. 23, 2018.

5. Urology Profile. Canadian Medical Association; Nov 2016. Available at https://www.cma.ca/assets/ assets-library/document/en/advocacy/profiles/urology-e.pdf. Accessed Feb. 23, 2018.

6. Canadian Institute of Health Information. National Health Expenditure Trends, 1975 to 2017. Available at https://www.cihi.ca/sites/default/files/document/nhex2017-trends-report-en.pdf. Accessed Feb. 23, 2018 .

Correspondence: Dr. Omar Nazif, Department of Urologic Sciences, University of British Columbia, Vancouver, BC, Canada; omar.nazif@ubc.ca

\section{NOW AVAILABLE! / MAINTENANT DISPONIBLE!}

\section{CUA GUIDELINES}

in French

\section{Topics include:}

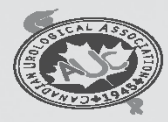

- CUA recommendations on prostate cancer screening and early diagnosis

- CUA guideline on the management of cystic renal lesions

- CUA guideline on adult overactive bladder

- CUA-PUC Canadian guidelines for the diagnosis, management and follow-up of cryptorchidism
GUIDES DE PRATIQUE 2017 DE L'AUC

\section{en français}

\section{Thèmes abordés :}

- Recommandations de l'AUC sur le dépistage et le diagnostic précoce du cancer de la prostate

- Guide de pratique sur la prise en charge des lésions kystiques aux reins

- Guide de pratique sur la vessie hyperactive chez l'adulte

- Guide de pratique AUC-UPC pour le diagnostic, la prise en charge et le suivi de la cryptorchidie au Canada

\section{cua.org cuaj.ca}

